\title{
Extent and Instability of Trimethylation of Histone H3 Lysine Increases With Degree of Malignancy and Methionine Addiction
}

\author{
JUN YAMAMOTO ${ }^{1,2,3}$, YUSUKE AOKI ${ }^{1,2}$, SACHIKO INUBUSHI ${ }^{1,2}$, QINGHONG HAN ${ }^{1}$, \\ KAZUYUKI HAMADA ${ }^{1,2}$, YOSHIHIKO TASHIRO ${ }^{1,2}$, KENTARO MIYAKE $^{3}$, RYUSEI MATSUYAMA ${ }^{3}$, \\ MICHAEL BOUVET ${ }^{2}$, STEVEN G. CLARKE ${ }^{4}$, ITARU ENDO ${ }^{3}$ and ROBERT M. HOFFMAN ${ }^{1,2}$ \\ ${ }^{1}$ AntiCancer Inc., San Diego, CA, U.S.A.; \\ ${ }^{2}$ Department of Surgery, University of California, San Diego, La Jolla, CA, U.S.A.; \\ ${ }^{3}$ Department of Gastroenterological Surgery, \\ Yokohama City University Graduate School of Medicine, Yokohama, Japan; \\ ${ }^{4}$ Department of Chemistry and Biochemistry, University of California, Los Angeles, CA, U.S.A.
}

\begin{abstract}
Background/Aim: Methionine addiction is a fundamental and general hallmark of cancer, termed the Hoffman effect. Methionine addiction is due to excessive use of and dependence on methionine by cancer cells. In the present report, we correlated the extent of methionine addiction and degree of malignancy with the amount and stability of methylated histone $\mathrm{H} 3$ lysine marks. Materials and Methods: We established low- and high-malignancy variants from a parental human pancreatic-cancer cell line and compared their sensitivity to methionine restriction and histone $\mathrm{H} 3$ lysine methylation status. Results: A low-malignancy, low-methionineaddiction revertant of the parental pancreatic-cancer cell line had less methylated H3K9me3 and was less sensitive to methionine restriction effected by recombinant methioninase (rMETase) than the parental cell line. A high-malignancy variant of the pancreatic cancer cell line had increased methylated H3K9me3 and was more sensitive to methionine
\end{abstract}

This article is freely accessible online.

Correspondence to: Robert M. Hoffman, Ph.D., AntiCancer Inc., 7917 Ostrow St, San Diego, CA, 92111, U.S.A. Tel: +1 8586542555, Fax: +18582684175, e-mail: all@anticancer.com; Itaru Endo, MD, Ph.D., Department of Gastroenterological Surgery, Yokohama City University Graduate School of Medicine, 3-9 Fukuura, Kanazawa-ku, Yokohama, 236-0004, Japan. Tel: +81 457872650, Fax: +81457829161, e-mail: endoit@yokohamacu.ac.jp; Jun Yamamoto, AntiCancer Inc., 7917 Ostrow St, San Diego, CA, 92111, U.S.A. Tel: +1 8586542555, Fax: +1 8582684175, e-mail: jun.ymmt.1014@gmail.com

Key Words: Methionine addiction, methionine dependence, methionine restriction, transmethylation, histone $\mathrm{H} 3$ lysine, overmethylation, lowmethionine-addiction revertant, high-methionine addiction variants, malignancy. restriction by rMETase with regard to inhibition of proliferation and to instability of histone $\mathrm{H} 3$ lysine methylation than the parental cell line. Orthotopic malignancy in nude mice was reduced in the low-methionine-addiction revertant and greater in the high-malignancy variant than in the parental cell line. Conclusion: The present study indicates that the degree of malignancy is linked to the extent of methionine addiction and the level and instability of trimethylation of histone $\mathrm{H3}$, suggesting these phenomena are linked as a fundamental basis of oncogenic transformation.

Methionine addiction (1) is a property of all types of cancer, termed the Hoffman effect (2-4). Methionine addiction of cancer has intense current interest, especially in the rapidly expanding field of diet and cancer (5-8). Methionine addiction is due to excess use of methionine by cancer cells for transmethylation reactions, resulting in dependence on exogenous methionine, despite high levels of endogenous synthesis of methionine (1,9-11).

The Hoffman effect may be greater than the Warburg effect as seen in comparison of methionine- and glucosebased positron-emission tomography (PET) imaging of cancer (12). Methionine restriction results in a block in the late $S / G_{2}$ phase of the cell cycle only in cancer cells, where they become sensitized to DNA-synthesis inhibitors (13-15). Excess transmethylation reactions in cancer cells results in overmethylation of trimethylated histone $\mathrm{H} 3$ lysine marks (16-18). Histone $\mathrm{H} 3$ overmethylation in cancer cells, but not normal cells, is unstable under methionine restriction (17). Rare methionine-independent revertants, which were selected by methionine restriction, are able to grow in conditions with low methionine or with precursors of methionine in place of methionine (18-20). The methionine-independent revertants lose overmethylation of trimethylated-histone H3 marks, as well as their malignancy $(18,20,21)$. 


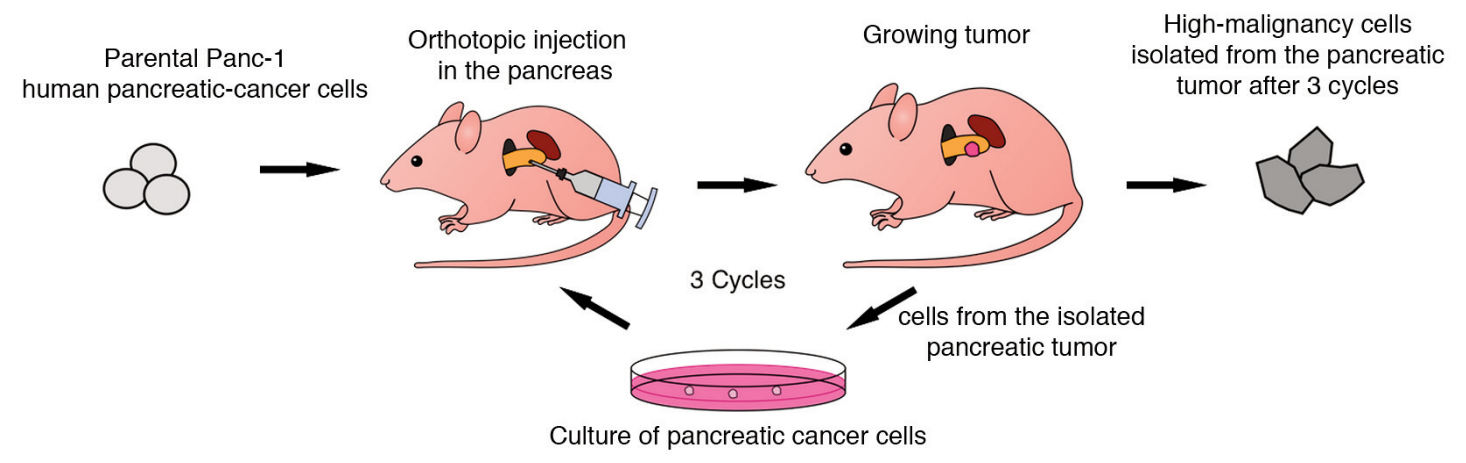

Figure 1. Diagram of the establishment of Panc-1-M cells through orthotopic-passage.

In the present report, we established a high-malignancy, highly methionine-addicted variant and a low-malignancy nonmethionine-addicted revertant from the same parental methionine-addicted cancer cell line, in which we demonstrate that the extent of methionine addiction is linked to the degree of malignancy and to the level and instability of trimethylation of histone $\mathrm{H} 3$ lysine marks.

\section{Materials and Methods}

Cell culture. Panc-1 human pancreatic cancer cells were obtained from the American Type Culture Collection (Manassas, VA, USA) and stably transduced to express green fluorescent protein (GFP) as previously described (21). Cells were cultured in Dulbecco's modified Eagle's medium (DMEM) supplemented with $10 \%$ fetal bovine serum (FBS) and $100 \mathrm{IU} / \mathrm{ml}$ penicillin/streptomycin.

Recombinant methioninase production. Methioninase [L-methionine $\alpha$-deamino- $\gamma$-mercapto-methane lyase (rMETase)] is a pyridoxalphosphate-dependent tetramer with each monomer having a molecular weight of $172 \mathrm{kDa}$. The methioninase gene was previously derived from Pseudomonas puvida (22), and cloned in Escherichia coli $(22,23)$. The production procedure, including fermentation, heating step, polyethylene-glycol precipitation and DEAE-Sepharose chromatography are described in our previous publication (23).

Isolation of low-methionine-addiction revertant cancer cells. Rare low-methionine-addiction revertant Panc-1 cells (Panc-1-R) were selected by resistance to rMETase (18).

In vivo isolation of high-malignancy variants. Isolation of highmalignancy variants of Panc-1 (Panc-1-M) was performed as previously described by orthotopic passage three times in nude mice (Figure 1), which resulted in cells with high malignancy (24).

Wound healing assay. Cells were cultured in 6 -well dishes $\left(8 \times 10^{5}\right.$ cells/well) and cell-free gaps were made by scratching a monolayer of $80 \%$ confluent cells with micro pipet tips. After washing the dishes three times with medium, the cells were incubated and the gap areas were measured at 12,24 and 36 hours after scratching (25).
Soft agar colony-formation assay. In 6-well dishes, $2.5 \mathrm{ml}$ of $0.7 \%$ agar in complete DMEM with $10 \%$ FBS and $100 \mathrm{IU} / \mathrm{ml}$ penicillin/streptomycin were placed as a lower layer. Then 5,000 cells were suspended in $2 \mathrm{ml}$ of $0.3 \%$ agar in complete DMEM with $10 \% \mathrm{FBS}$ and $100 \mathrm{IU} / \mathrm{ml}$ penicillin/streptomycin and layered on top of the bottom layer. Cells were cultured for 14 days and resulting colonies were stained with $0.01 \%$ crystal violet and counted (20).

Efficacy of rMETase on viability of cancer cells in vitro. Cells were cultured in 96-well plates $\left(2 \times 10^{3}\right.$ cells/well $)$ and treated with rMETase ( $0.05 \mathrm{U} / \mathrm{ml}$ to $6.4 \mathrm{U} / \mathrm{ml}$ ) for 96 hours. A Cell-Counting Kit-8 (Dojindo, Kumamoto, Japan) was used to construct growth curves and halfmaximal inhibitory concentrations $\left(\mathrm{IC}_{50}\right)$ of r-METase were calculated as described previously (17).

Immunoblotting. Anti-H3K9me1 (1:1,000, \#14186; Cell Signaling Technology, Danvers, MA, USA); anti-H3K9me2 (1:1,000, \#4658; Cell Signaling Technology) or anti-H3K9me3 (1:1,000, \#13969; Cell Signaling Technology) were used as primary antibodies. Total histone H3 (1:5,000, 17168-1-AP; Proteintech, Rosemont, IL, USA) was used as a loading control. Previously-described techniques were used for histone extraction, immunoblotting and signal detection $(17,26-28)$.

Determination of tumorgenicity of parental cancer cells, lowmethionine-addiction revertants and high-malignancy cancer cells in an orthotopic mouse model. Nude-mouse (AntiCancer Inc, San Diego, CA, USA) studies were performed with an AntiCancer Institutional Animal Care and Use Committee (IACUC)-protocol following the National Institutes of Health Guide for the Care and Use of Animals under Assurance Number A3873-1 (26).

Panc- 1 cells, Panc-1-R cells and Panc-1-M cells $\left(0.5 \times 10^{6}\right.$ or $1 \times 10^{6}$ cells $/ 50 \mu \mathrm{PBS}$ ) were injected orthotopically into the pancreas of five nude mice and grown for 42 days, at which point the tumor weight was measured.

Statistical analyses. JMP PRO ver. 15.0.0 (SAS Institute, Cary, NC, USA) was used for statistical analysis. Comparisons between groups of used the Mann-Whitney $U$-test. Error bars on the graphs represent the standard error of the mean. A probability value of $p<0.05$ was defined as statistically significant. 
A

Panc-1

Panc-1-R

Panc-1-M
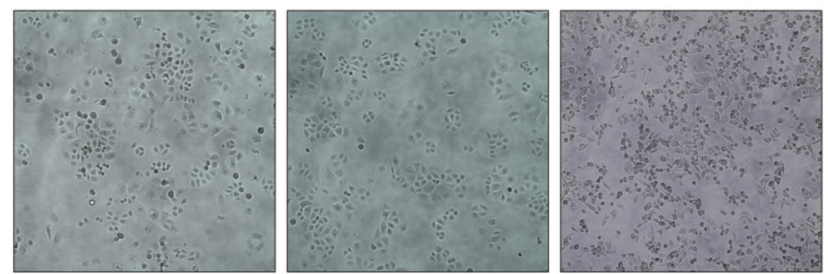

B

$\mathrm{Oh}$

$12 \mathrm{~h}$

$24 \mathrm{~h}$

$36 \mathrm{~h}$
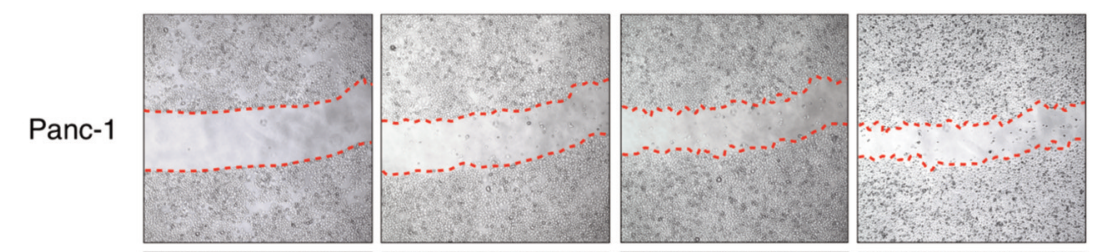

Panc-1-R
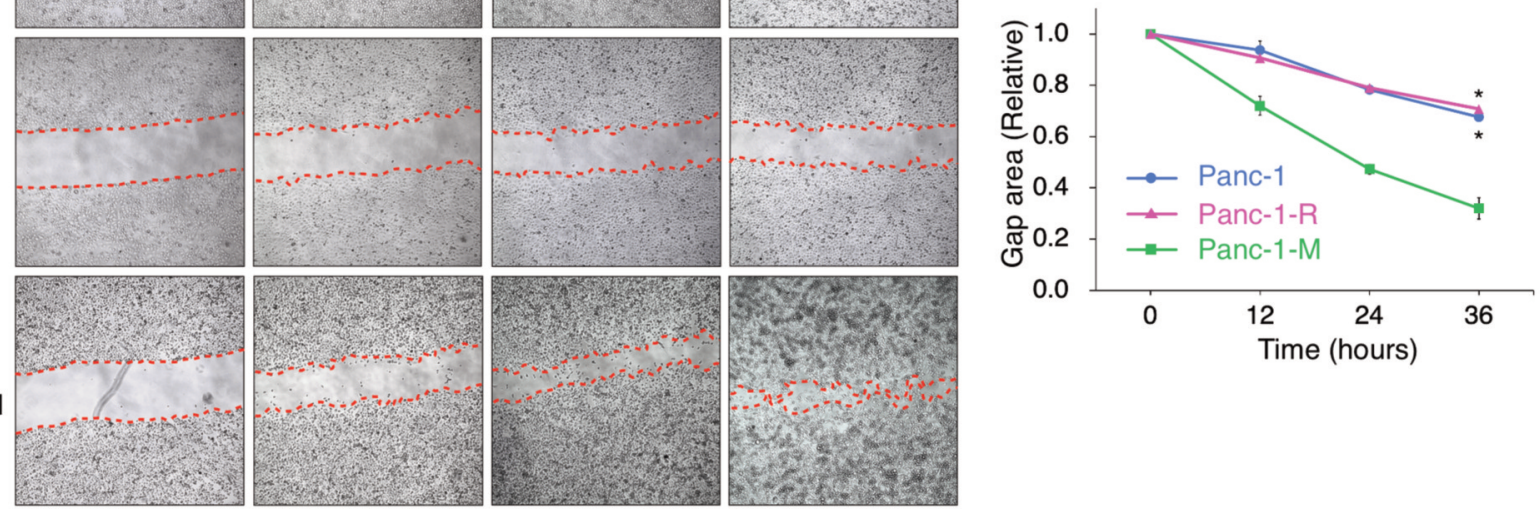

C

Panc-1

Panc-1-R
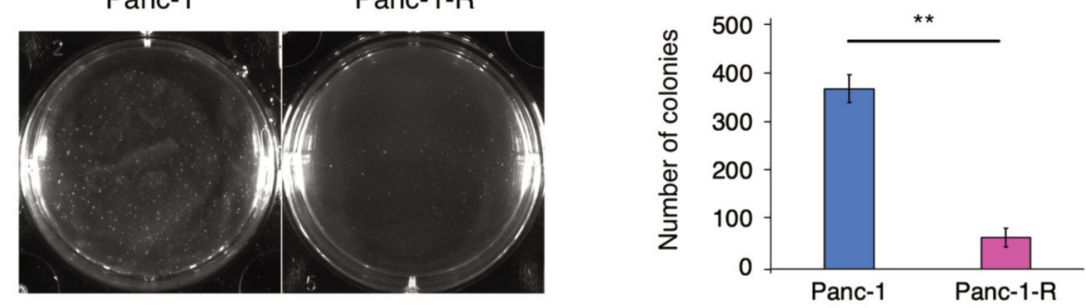

D

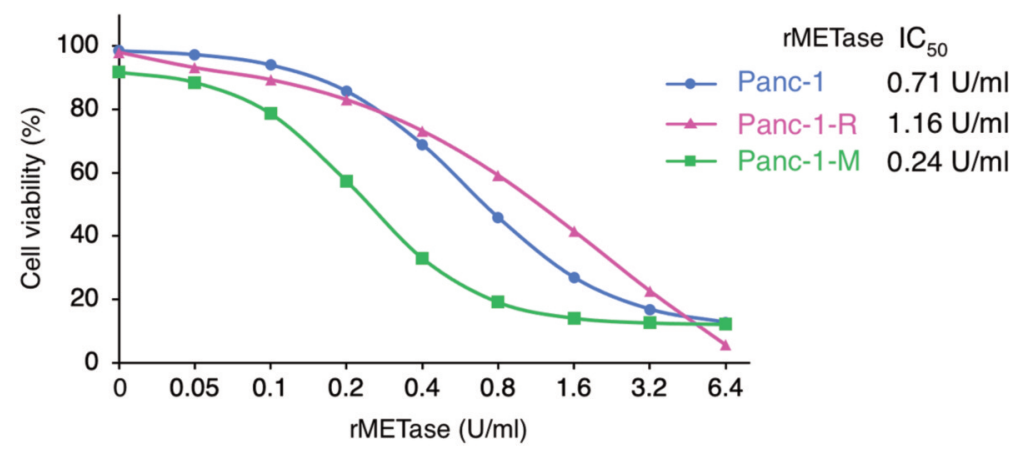

Figure 2. Comparison of malignancy between parental Panc-1 cells, low-methionine- addiction revertant Panc-1-R cells and high-malignancy Panc1-M cells in vitro. A: Morphology of parental Panc-1 cells, Panc-1-R cells and Panc-1-M cells $(\times 100)$. B: Wound-healing assay in Panc-1 cells, Panc-1-R cells and Panc-1-M cells. Left: Representative images at 0, 12, 24 and 36 hours after the wounding scratch was made (x40). Right: Graph of the relative gap area (mean \pm SEM, $n=3)$. *Significantly different from Panc-1-M cells at $p=0.001$. C: Colony-formation assay of parental Panc-1 cells and Panc-1-R cells. Left: Representative image at 14 days of culture. Right: Bar graph of the number of colonies at 14 days of culture (mean $\pm S E M, n=3 . * * p<0.0001)$. D: Sensitivity to recombinant methioninase (rMETase). Parental Panc-1 cells, Panc-1-R cells and Panc-1-M cells were cultured for 96 hours with different concentrations of rMETase $(n=3) . I C_{50}$ : Half-maximal inhibitory concentration. 
A

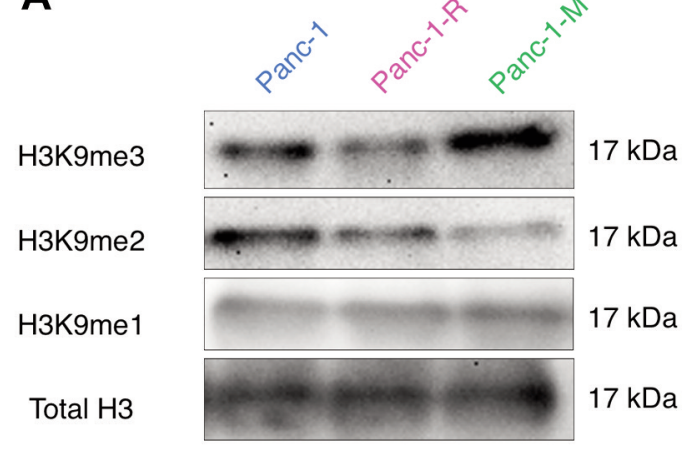

B

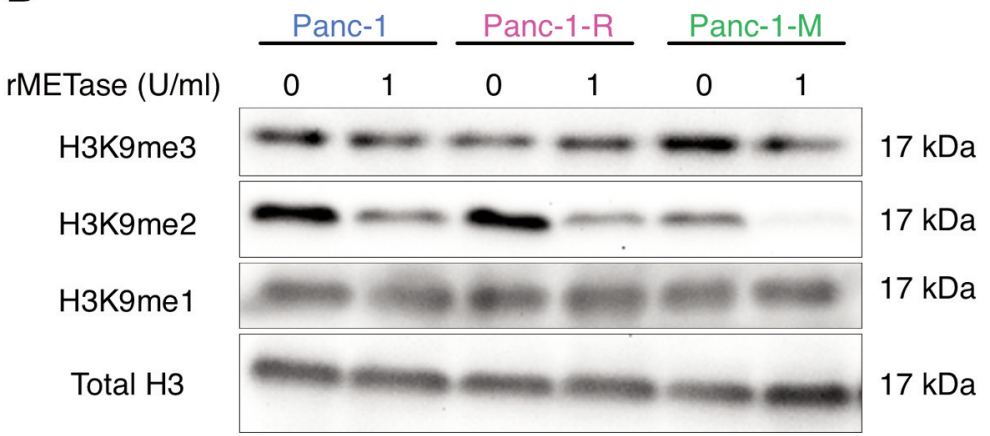

Figure 3. Comparison of histone H3 lysine methylation between parental Panc-1 cells, low-methionine-addiction revertant Panc-1-R cells and highmalignancy Panc-1-M cells in vitro. A: Immunoblot of H3K9me1, H3K9me2 and H3K9me3 in Panc-1, Panc-1-R and Panc-1-M cells. B: Immunoblot of H3K9me1, H3K9me2 and H3K9me3 in parental Panc-1 cells, Panc-1-R cells and Panc-1-M cells treated with (1) or without (0) 1 U/ml of rMETase.

\section{Results}

In vitro malignancy characteristics and methionine addiction are elevated in orthotopically-passaged cancer cells and are reduced in low-methionine-addiction revertants. We first compared malignancy characteristics between parental Panc1 cells, Panc-1-R low-methionine-addiction revertant and orthotopically-passaged Panc-1-M cells in vitro. There was no apparent difference of morphology between parental Panc-1 cells and Panc-1-R cells. In contrast, the morphology of the Panc-1-M cells changed from round to spindle shape (Figure 2A). There was no difference in the speed of wound healing between parental cells and Panc-1-R cells. In contrast, the speed of wound healing was faster in Panc-1$\mathrm{M}$ cells compared to parental Panc-1 cells and Panc-1-R cells $(p=0.001)$ (Figure 2B). The number of the colonies formed in soft agar was significantly lower in Panc-1-R cells compared to parental Panc-1 cells $(p<0.0001)$ (Figure 2C). These results indicate that malignancy was elevated in the orthotopic-passaged Panc-1-M cancer cells and reduced in Panc-1-R cells compared to parental Panc-1 cells in vitro.

To evaluate the methionine addiction of parental Panc-1 cells, low-malignancy Panc-1-R cells and high-malignancy Panc-1-M cells, their sensitivity to rMETase was compared. The half-maximal inhibitory concentration $\left(\mathrm{IC}_{50}\right)$ of rMETase was higher in Panc-1-R cells and lower in Panc-1-M cells than parental Panc-1-cells respectively $\left(\mathrm{IC}_{50}\right.$ : Panc-1: $0.71 \mathrm{U} / \mathrm{ml}$; Panc-1-R: $1.16 \mathrm{U} / \mathrm{ml}$; Panc-1-M: 0.24 U/ml) (Figure 2D). These results indicate that the higher the malignancy of the cells, the more they are addicted to methionine as indicated by the increased sensitivity to methioninase.

Methionine addiction is linked to malignancy and the overmethylation of $\mathrm{H} 3 \mathrm{~K} 9 \mathrm{me} 3$ in vitro. We then compared the histone methylation status of $\mathrm{H} 3 \mathrm{~K} 9$ marks between parental
Panc-1, Panc-1-R and Panc-1-M cells cultured in vitro. The level of H3K9me3 was elevated in Panc-1-M cells and was reduced in Panc-1-R cells compared to parental Panc-1 cells (Figure 3A). The level of H3K9me2 was reduced in highmalignancy Panc-1-M cells compared to parental Panc-1 cells and Panc-1-R cells. There was no apparent difference in the levels of $\mathrm{H} 3 \mathrm{~K} 9 \mathrm{mel}$ between the three types of the cells.

We also compared the stability of histone methylation status under rMETase action. The level of H3K9me3 was reduced by rMETase in parental Panc-1 cells and Panc-1-M cells. In contrast, the level of $\mathrm{H} 3 \mathrm{~K} 9 \mathrm{me} 3$ was not altered by rMETase in Panc-1-R cells (Figure 3B). The level of H3K9me2 was reduced in all three cell lines by rMETase. The level of H3K9me1 was not apparently altered by rMETase in any of the cell lines. These results indicate that methionine addiction is linked to malignancy and unstable overmethylation of $\mathrm{H} 3 \mathrm{~K} 9 \mathrm{me} 3$ in vitro.

Methionine addiction and the level of $H 3 \mathrm{~K} 9 \mathrm{me} 3$ are linked to degree of tumorigenicity. To compare the in vivo malignancy of parental Panc-1 cells, low-methionine-addiction revertant Panc1-R cells and high-malignancy, high methionine-addicted Panc$1-\mathrm{M}$ cells, the tumorigenicity and metastatic capability of these cells was compared in an orthotopic xenograft mouse model. Panc-1-M cells formed tumors in 5/5 nude mice when $0.5 \times 10^{6}$ cells were injected, compared to $3 / 5$ mice with tumors from Panc-1 and 0/5 mice with tumors from Panc-1-R (Figure 4A). The mean tumor weight was significantly higher in Panc-1-M tumors compared to Panc-1 and Panc-1-R tumors after injection of $1 \times 10^{6}$ cells in the nude-mouse pancreas $(p<0.001)$ (Figure $4 \mathrm{~B}$ and C). Only the Panc-1-M cells formed metastases (Figure 4D). Immunoblotting showed that the level of $\mathrm{H} 3 \mathrm{~K} 9$ me3 was lower in Panc-1-R tumors and higher in Panc-1-M tumors than in parental Panc-1 tumors (Figure 4E). These results indicate that the extent of methionine addiction is linked to the degree of malignancy and to overmethylation of $\mathrm{H} 3 \mathrm{~K} 9 \mathrm{me} 3$ in vivo. 
A

\begin{tabular}{|c|c|c|c|c|}
\hline $\begin{array}{l}\text { Number } \\
\text { of cells } \\
\text { injected }\end{array}$ & \multicolumn{2}{|c|}{$0.5 \times 10^{6}$ cells } & \multicolumn{2}{|c|}{$1 \times 10^{6}$ cells } \\
\hline Cell line & $\begin{array}{r}\text { Primary } \\
\text { tumors } \\
\text { (numb }\end{array}$ & $\begin{array}{l}\text { Metastasis } \\
\text { of mice) }\end{array}$ & $\begin{array}{r}\text { Primary } \\
\text { tumors } \\
\text { (nc }\end{array}$ & $\begin{array}{l}\text { Metastasis } \\
\text { ber of mice) }\end{array}$ \\
\hline Panc-1 & $3 / 5$ & $0 / 5$ & $4 / 5$ & $0 / 5$ \\
\hline Panc-1-R & $0 / 5$ & $0 / 5$ & $2 / 5$ & $0 / 5$ \\
\hline Panc-1-M & $5 / 5$ & $\begin{array}{c}1 / 5 \\
\text { (Peritoneal) }\end{array}$ & $5 / 5$ & $\begin{array}{c}1 / 5 \\
\text { (Peritoneal, Liver) }\end{array}$ \\
\hline
\end{tabular}

C Panc-1

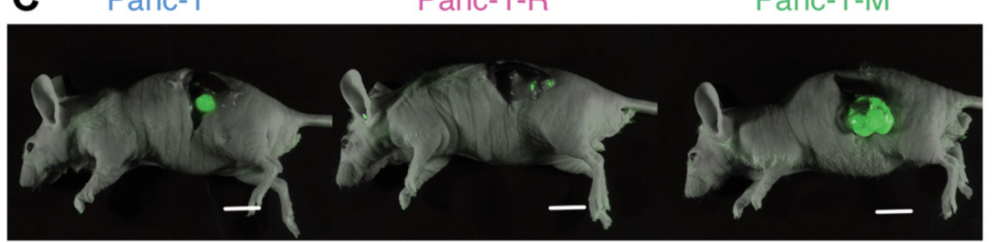

D
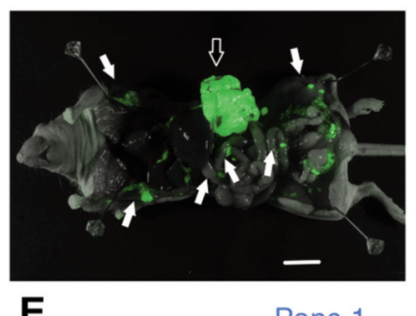

B

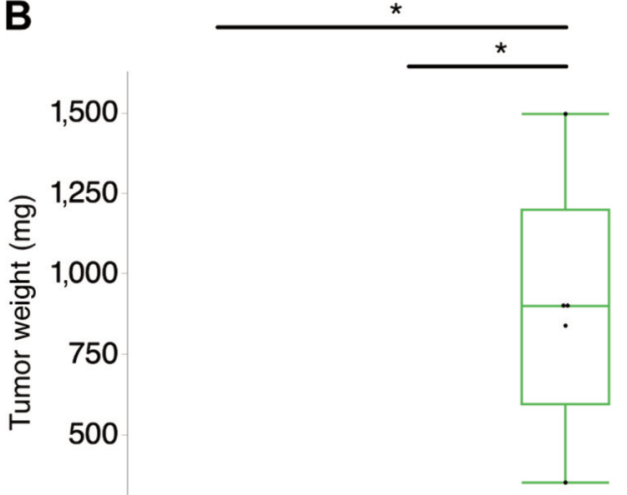

250

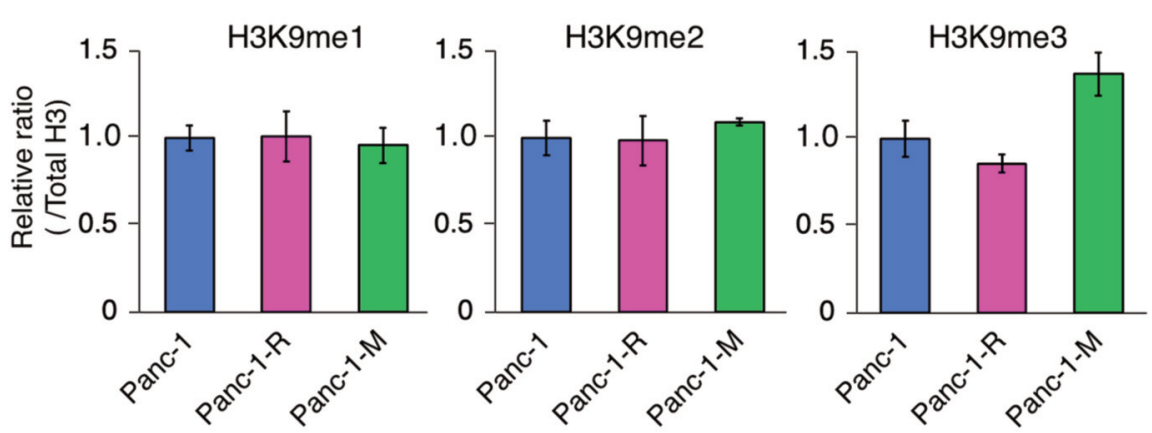

Figure 4. Orthotopic tumorigenicity and histone H3K9 methylation study in parental Panc-1 cells, low-malignancy Panc-1-R cells and highmalignancy Panc-1-M cells. A: The number of mice with tumors formed by Panc-1, Panc-1-R and Panc-1-M cells after injection of $0.5 \times 10^{6}$ or $1 \times 10^{6}$ cells. B: The weight of tumors formed by Panc-1, Panc-1-R and Panc-1-M cells 42 days after $1 \times 10^{6}$ cells were injected $(n=5 ; * * p<0.001)$. $C$ : Representative GFP fluorescence images of tumors formed by Panc-1, Panc-1-R and Panc-1-M cells $\left(1 \times 10^{6} \mathrm{cells}\right)$. White bar: $1 \mathrm{~cm} . D:$ GFP Fluorescence image of multiple peritoneal dissemination in a mouse injected with Panc-1-M cells $\left(1 \times 10^{6}\right.$ cells). Black arrow: Primary pancreatic tumor. White arrows: Peritoneal dissemination. E: Immunoblot of H3K9me1, H3K9me2 and H3K9me3 in orthotopic tumors formed from Panc-1, Panc-1-R and Panc-1-M (Panc-1 and Panc-1-M: n=3. Panc-1-R: n=2). Upper panel: Images of immunoblots. Lower panel: Ratio of H3K9me1, H3K9me 2 and H3K9me3 to total $\mathrm{H} 3$ in the tumors formed in mice by Panc-1, Panc-1-R and Panc-1-M cells (mean $\pm S D)$. 


\section{Discussion}

The present report increases our understanding of the relationship of the methionine addiction of cancer, first discovered in 1976 by one of us (RMH) (1), malignancy and histone H3 lysine methylation. A crucial aspect of the present study was to isolate both low-malignancy and high-malignancy variants of the pancreatic cancer cell line Panc-1. The low-malignancy variant was selected by resistance to methioninase, and thereby the isolated variant developed low-methionine addiction and was termed a 'methionine-independent revertant' of methionineaddicted cells (17-20). The high-malignancy variant was isolated by several passages of the parental cells orthotopically from nude mouse to nude mouse. The low-methionine-addiction revertant Panc-1-R lost tumorigenicity at $0.5 \times 10^{6}$ cells /mouse; the parental cells were intermediate in tumorigenicity and the high-malignancy Panc-1-M cells had $100 \%$ tumorigenicity and only Panc-1-M was able to form metastases. The methioninase- sensitivity studies showed that methionine addiction is linked to the degree of malignancy in the present report. Breillout et al., more than 30 years ago, found that cancer cells selected for increasing malignancy required more methionine (29). The present study, which isolated both low- and high-malignancy variants of Panc1 , has shown that methionine addiction is linked to malignancy. Wang et al. also showed that tumor-initiating cells are more addicted to exogenous methionine than non-tumor-initiating cancer cells (7), confirming our original results (1).

Our recent study showed that methionine-independent revertants isolated from methionine-addicted cancer cells lose the overmethylation of trimethylated histone $\mathrm{H} 3$ marks, and their malignancy (18). We had also shown earlier that low-methionineaddicted revertants lost malignancy characteristics $(20,21)$. Raboni et al. confirmed that methioninase treatment results in loss or reduction of histone lysine marks in methionine-addicted cancer cells (4). The present study is the first in which the histone methylation status and stability, and malignancy were compared between three types of malignancy variants which have different dependence on methionine.

The present study demonstrates that methylation of $\mathrm{H} 3 \mathrm{~K} 9 \mathrm{me} 3$ increases with malignancy as well as with methionine addiction starting from low-malignant lowmethionine-addiction revertant cells to high-malignancy high-methionine-addiction cells. These results suggest that methionine addiction is linked to overmethylation of H3K9me3 and both are linked to malignancy, suggesting methionine addiction and overmethylation are a fundamental basis of oncogenic transformation (14, 27-29).

\section{Conflicts of Interest}

JY, YA, SI, KH, YT and RMH are or were unsalaried associates of AntiCancer Inc.QH is an employee of AntiCancer Inc. The Authors declare that there are no potential conflicts of interest.

\section{Authors' Contributions}

JY and RMH designed and performed experiments and wrote the paper; YA, SI, QH, KH, YT, KM, RM, MB and SGC gave technical support and conceptual advice. Writing, review, and/or revision of the article: JY, IE and RMH.

\section{Acknowledgements}

This work was supported in part by a Yokohama City University research grant "KAMOME Project". The study was also supported in part by the Robert M. Hoffman Foundation for Cancer Research. Neither organization had a role in the design, execution, interpretation, or writing of the study. This article is dedicated to the memory of A. R. Moossa, M.D., Sun Lee, M.D., Professor Li Jiaxi, Masaki Kitajima, MD, and Joseph R. Bertino, M.D.

\section{References}

1 Hoffman RM and Erbe RW: High in vivo rates of methionine biosynthesis in transformed human and malignant rat cells auxotrophic for methionine. Proc Natl Acad Sci USA 73(5): 1523-1527, 1976. PMID: 179090. DOI: 10.1073/pnas.73.5.1523

2 Kaiser P: Methionine dependence of cancer. Biomolecules 10(4): 568, 2020. PMID: 32276408. DOI: 10.3390/biom10040568

3 Endicott M, Jones M and Hull J: Amino acid metabolism as a therapeutic target in cancer: a review. Amino Acids 53(8): 11691179, 2021. PMID: 34292410. DOI: 10.1007/s00726-021-03052-1

4 Raboni S, Montalbano S, Stransky S, Garcia BA, Buschini A, Bettati S, Sidoli S and Mozzarelli A: A key silencing histone mark on chromatin is lost when colorectal adenocarcinoma cells are depleted of methionine by methionine $\gamma$-lyase. Front Mol Biosci 8 : 735303, 2021. PMID: 34660696. DOI: 10.3389/fmolb.2021.735303

5 Gao X, Sanderson SM, Dai Z, Reid MA, Cooper DE, Lu M, Richie JP Jr, Ciccarella A, Calcagnotto A, Mikhael PG, Mentch SJ, Liu J, Ables G, Kirsch DG, Hsu DS, Nichenametla SN and Locasale JW: Dietary methionine influences therapy in mouse cancer models and alters human metabolism. Nature 572(7769): 397-401, 2019. PMID: 31367041. DOI: 10.1038/s41586-019-1437-3

6 Sanderson SM, Gao X, Dai Z and Locasale JW: Methionine metabolism in health and cancer: a nexus of diet and precision medicine. Nat Rev Cancer 19(11): 625-637, 2019. PMID: 31515518. DOI: 10.1038/s41568-019-0187-8

7 Wang Z, Yip LY, Lee JHJ, Wu Z, Chew HY, Chong PKW, Teo CC, Ang HY, Peh KLE, Yuan J, Ma S, Choo LSK, Basri N, Jiang X, Yu Q, Hillmer AM, Lim WT, Lim TKH, Takano A, Tan EH, Tan DSW, Ho YS, Lim B and Tam WL: Methionine is a metabolic dependency of tumor-initiating cells. Nat Med 25(5): 825-837, 2019. PMID: 31061538. DOI: 10.1038/s41591-019-0423-5

8 Kanarek N, Petrova B and Sabatini DM: Dietary modifications for enhanced cancer therapy. Nature 579(7800): 507-517, 2020. PMID: 32214253. DOI: 10.1038/s41586-020-2124-0

9 Coalson DW, Mecham JO, Stern PH and Hoffman RM: Reduced availability of endogenously synthesized methionine for Sadenosylmethionine formation in methionine-dependent cancer cells. Proc Natl Acad Sci USA 79(14): 4248-4251, 1982. PMID: 6289297. DOI: 10.1073/pnas.79.14.4248

10 Stern PH, Mecham JO, Wallace CD and Hoffman RM: Reduced free-methionine in methionine-dependent SV40-transformed 
human fibroblasts synthesizing apparently normal amounts of methionine. J Cell Physiol 117(1): 9-14, 1983. PMID: 6311851. DOI: $10.1002 /$ jep.1041170103

11 Stern PH, Wallace CD and Hoffman RM: Altered methionine metabolism occurs in all members of a set of diverse human tumor cell lines. J Cell Physiol 119(1): 29-34, 1984. PMID: 6707100. DOI: $10.1002 / \mathrm{jcp} .1041190106$

12 Pirotte B, Goldman S, Massager N, David P, Wikler D, Vandesteene A, Salmon I, Brotchi J and Levivier M: Comparison of ${ }^{18} \mathrm{~F}$-FDG and ${ }^{11} \mathrm{C}$-methionine for PET-guided stereotactic brain biopsy of gliomas. J Nucl Med 45(8): 1293-1298, 2004. PMID: 15299051.

13 Hoffman RM and Jacobsen SJ: Reversible growth arrest in simian virus 40-transformed human fibroblasts. Proc Natl Acad Sci USA 77(12): 7306-7310, 1980. PMID: 6261250. DOI: 10.1073/pnas. 77.12 .7306

14 Guo H, Lishko VK, Herrera H, Groce A, Kubota T and Hoffman RM: Therapeutic tumor-specific cell cycle block induced by methionine starvation in vivo. Cancer Res 53(23): 5676-5679, 1993. PMID: 8242623.

15 Yano S, Li S, Han Q, Tan Y, Bouvet M, Fujiwara T and Hoffman RM: Selective methioninase-induced trap of cancer cells in S/G2 phase visualized by FUCCI imaging confers chemosensitivity. Oncotarget 5(18): 8729-8736, 2014. PMID: 25238266. DOI: 10.18632 /oncotarget.2369

16 Stern PH and Hoffman RM: Elevated overall rates of transmethylation in cell lines from diverse human tumors. In Vitro 20(8): 663-670, 1984. PMID: 6500606. DOI: 10.1007/BF02619617

17 Yamamoto J, Han Q, Inubushi S, Sugisawa N, Hamada K, Nishino H, Miyake K, Kumamoto T, Matsuyama R, Bouvet M, Endo I and Hoffman RM: Histone methylation status of $\mathrm{H} 3 \mathrm{~K} 4 \mathrm{me} 3$ and $\mathrm{H} 3 \mathrm{~K} 9 \mathrm{me} 3$ under methionine restriction is unstable in methionine-addicted cancer cells, but stable in normal cells. Biochem Biophys Res Commun 533(4): 10341038, 2020. PMID: 33019978. DOI: 10.1016/j.bbrc.2020.09.108

18 Yamamoto J, Inubushi S, Han Q, Tashiro Y, Sugisawa N, Hamada K, Aoki Y, Miyake K, Matsuyama R, Bouvet M, Clarke S, Endo I and Hoffman R: The linkage of methionine addiction, overmethylation of histone $\mathrm{H} 3$ lysines and malignancy demonstrated when cancer cells revert to methionineindependence. bioRxiv, 2021. DOI: 10.1101/2020.12.04.412437

19 Hoffman RM, Jacobsen SJ and Erbe RW: Reversion to methionine independence by malignant rat and SV40-transformed human fibroblasts. Biochem Biophys Res Commun 82(1): 228-234, 1978. PMID: 208554. DOI: 10.1016/0006-291x(78)90600-9

20 Hoffman RM, Jacobsen SJ and Erbe RW: Reversion to methionine independence in simian virus 40-transformed human and malignant rat fibroblasts is associated with altered ploidy and altered properties of transformation. Proc Natl Acad Sci USA 76(3): 13131317, 1979. PMID: 220612. DOI: 10.1073/pnas.76.3.1313

21 Yamamoto J, Aoki Y, Han Q, Sugisawa N, Sun YU, Hamada K, Nishino H, Inubushi S, Miyake K, Matsuyama R, Bouvet M, Endo I and Hoffman RM: Reversion from methionine addiction to methionine independence results in loss of tumorigenic potential of highly-malignant lung-cancer cells. Anticancer Res 41(2): 641643, 2021. PMID: 33517268. DOI: 10.21873/anticanres.14815
22 Kudou D, Misaki S, Yamashita M, Tamura T, Takakura T, Yoshioka T, Yagi S, Hoffman RM, Takimoto A, Esaki N and Inagaki K: Structure of the antitumour enzyme L-methionine gamma-lyase from Pseudomonas putida at 1.8 A resolution. J Biochem 141(4): 535-544, 2007. PMID: 17289792. DOI: $10.1093 / \mathrm{jb} / \mathrm{mvm} 055$

23 Tan Y, Xu M, Tan X, Tan X, Wang X, Saikawa Y, Nagahama T, Sun X, Lenz M and Hoffman RM: Overexpression and largescale production of recombinant L-methionine-alpha-deaminogamma-mercaptomethane-lyase for novel anticancer therapy. Protein Expr Purif 9(2): 233-245, 1997. PMID: 9056489. DOI: 10.1006/prep.1996.0700

24 Takahashi K, Ehata S, Koinuma D, Morishita Y, Soda M, Mano $\mathrm{H}$ and Miyazono K: Pancreatic tumor microenvironment confers highly malignant properties on pancreatic cancer cells. Oncogene 37(21): 2757-2772, 2018. PMID: 29511349. DOI: 10.1038/s41388-018-0144-0

25 Rodriguez LG, Wu X and Guan JL: Wound-healing assay. Methods Mol Biol 294: 23-29, 2005. PMID: 15576902. DOI: 10.1385/1-59259-860-9:023

26 Yamamoto J, Miyake K, Han Q, Tan Y, Inubushi S, Sugisawa N, Higuchi T, Tashiro Y, Nishino H, Homma Y, Matsuyama R, Chawla SP, Bouvet M, Singh SR, Endo I and Hoffman RM: Oral recombinant methioninase increases TRAIL receptor-2 expression to regress pancreatic cancer in combination with agonist tigatuzumab in an orthotopic mouse model. Cancer Lett 492: 174184, 2020. PMID: 32739322. DOI: 10.1016/j.canlet.2020.07.034

27 Aoki Y, Yamamoto J, Tome Y, Hamada K, Masaki N, Inubushi S, Tashiro Y, Bouvet M, Endo I, Nishida K and Hoffman RM: Overmethylation of Histone H3 Lysines Is a Common Molecular Change Among the Three Major Types of Soft-tissue Sarcoma in Patient-derived Xenograft (PDX) Mouse Models. Cancer Genomics Proteomics 18(6): 715-721, 2021. PMID: 34697064. DOI: $10.21873 / \operatorname{cgp} .20292$

28 Aoki Y, Tome Y, Han Q, Yamamoto J, Hamada K, Masaki N, Bouvet M, Nishida K and Hoffman RM: Histone H3 lysinetrimethylation markers are decreased by recombinant methioninase and increased by methotrexate at concentrations which inhibit methionine-addicted osteosarcoma cell proliferation. Biochem Biophys Rep 28: 101177, 2021. DOI: 10.1016/j.bbrep.2021.101177

29 Breillout F, Antoine E and Poupon MF: Methionine dependency of malignant tumors: a possible approach for therapy. J Natl Cancer Inst 82(20): 1628-1632, 1990. PMID: 2213904. DOI: $10.1093 /$ jnci/82.20.1628 